\title{
AC 2007-965: GAUGING STUDENT INTEREST IN A DESIGN FOR DEVELOPING COMMUNITIES COURSES AT THE UNIVERSITY OF HARTFORD
}

\section{David Pines, University of Hartford}

David Pines is an Associate Professor of Civil and Environmental Engineering at the University of Hartford. He completed his Ph.D. studies in the Department of Civil and Environmental Engineering at the University of Massachusetts, Amherst in 2000. He is actively involved with student projects sponsored by environmental engineering firms, municipalities, and water utilities, and is involved in international service learning projects in conjunction with EWB. 


\title{
Gauging Student Interest in a Design for Developing Communities Course at the University of Hartford
}

\begin{abstract}
Community service learning projects are an important part of the curriculum in the College of Engineering, Technology, and Architecture at the University of Hartford. To further this service learning experience, an interdisciplinary engineering course has been developed to provide interested students an opportunity to design and implement a project for a developing community. During the second semester of the sophomore year, students are given a choice to work on a contemporary engineering problem. Starting in spring 2007 semester, a design for developing communities' project had been included as one of the projects. In addition to learning about sustainable design, students will have the opportunity to implement their design over the summer where they will learn about "on-location" issues that can not be duplicated in the classroom. The interest in providing students this type of opportunity has grown dramatically in the last several years as indicated by the number of papers being presented at engineering education conferences on this subject and the growth of organizations such as Engineers Without Borders $(\mathrm{EWB})^{1}$. This paper summarizes how a design for developing communities course was added to the curriculum and the challenges involved in providing the students the opportunity to implement their project on-site without having to spend an inordinate amount of time fundraising. Furthermore, the results of a survey assessing students' level of interest for working on this type of project are also discussed.
\end{abstract}

\section{Introduction}

The engineering programs at the University of Hartford include a project based design course in each year of the curriculum. Within this format, the sophomore and junior year design courses provide an excellent opportunity for these to be service learning projects. These projects directly support the University's mission statement which emphasizes that taking an active role in the community is an important element of a student's preparation for a lifetime of learning and personal and professional success. Furthermore, the University of Hartford also strives to offer its students a complete education, one that will prepare them for the challenges of the global community of the 21 st century $^{2}$. Numerous examples of these type of research and design projects have been described in previous ASEE conference papers and assessment of the service learning projects by community sponsors, faculty, alumni, and students has been very positive $^{3,4,5}$. However, most of the projects focused on the Greater Hartford area and do not give the students a perspective of the global challenges they will face throughout their engineering career.

To meet the goal of preparing our students with meeting the challenges of the global community, it was decided to provide students an opportunity to work on a design for developing community project in their sophomore design course. The basis for selecting the sophomore design course as opposed to other alternatives considered was discussed in a previous paper ${ }^{6}$. In summary, it was concluded that is was not feasible to add a required course to the curriculum because of the 
pressure to reduce the total credit hours so that students can complete their engineering degree in four years. Also, the elimination of a required course is difficult at this time because all of the required courses that have survived recent "course reduction" exercises are considered "essential" by at least some of the faculty. Finally, the faculty was not in favor of eliminating another professional elective because it was felt that students should be able to select at least three courses that meet their professional needs. (The civil engineering curricula and description of the courses can be found at http://uhaweb.hartford.edu/CEE.) The existing sophomore design course was selected instead of the junior or senior level design courses because of the desire to have students who have gained "on-site" experience be available to mentor students the following year(s) so that their expertise is not lost. Also, this will provide those students most interested in design for developing communities to be involved in a leadership role in subsequent projects. In order for the students to be fully engaged in the technical aspects of the project while still at an early stage in their engineering education, the instructor will rely on "just in time learning" to teach the technical material and sustainable design concepts that support the project requirements.

A previous paper $^{6}$ also discussed the challenges that must be overcome in offering a design for developing community project that includes the opportunity for interested students to travel to the community and implement their design. The "on-location" learning is an important aspect for these types of projects that can not be duplicated in the classroom. Through the support of Pratt \& Whitney's desire to be a sponsor of an Engineers Without Borders project, the financial burden has been significantly diminished. This will allow the student to concentrate on learning about sustainable development issues and the opportunity to implement their project without having to spend an inordinate amount of time fund raising. Also, this support will help to sustain an Engineering for Developing Community course on a long term basis.

\section{Design for Developing Community Project}

Through a University of Hartford's faculty contact with a an NGO in India (Navjyoti), it was learned that Abheypur village which is located in the eastern part of Gurgon district in the state of Haryana (about $30 \mathrm{~km}$ from New Delhi) has a potable water supply problem. The village is located near the Aravallis Hills, which is a semiarid area. Even though the village is located near a highway, the transport facilities in the village are poor. Per the census of 2001, the population of the village is 3418 with 272 households. The village primarily consists of agriculture (wheat, bajra, and mustard) and dairy. The farmers have tube wells that are used to irrigate their crops. About $55 \%$ of the villagers are unemployed and a majority is illiterate and depends on daily wage earnings (i.e., laborers).

Prior to January 2006, the water supply for the village consisted of two pumps that are only operable when the electricity comes on, which is typically only for 2 to 3 hours per day and sometimes at night. Women generally spend four to five hours per day waiting in long lines to collect 10 liters of water. Even with this time and effort, there is no guarantee of water if the electricity goes off before they get a chance to fill their vessels. Also, there are five wells (about 50 feet deep) that are not functional because it is estimated that the water table is at a depth of about 200 feet at the foothills and 60 feet in the plains. Annual rainfall between 1992 and 2002 
has ranged from 392 to $661 \mathrm{~mm}$ with an average of $530 \mathrm{~mm}$ (Source: District Hydrological Office, Gurgon).

In January 2006, two new wells were drilled that use hand pumps. While no longer dependent on the electric grid, the time required for the women to get the necessary water $(\sim 10$ liters per day per person) is still significant because of the time required to wait in line, fill their vessels, and transport them back and forth to their homes. To further complicate the issue, the untouchables must get water from outside the village in Damdana, which is $1.5 \mathrm{~km}$ away, because they are not allowed to get water from the common source. For them to have direct access to water, the water supply must be located in the foothills where they live.

The water problems are recognized by the people and want the Panchayat (self-governing body) to improve the situation. Approval of the village's Panchayat is required before any project can proceed. The Panchayat consists of five people that are elected by the villagers and is headed by a person called the "Sarpanch." With the decline in traditional systems that linked water with religious activities (e.g., "Johad Puja" which means worshipping of pond and "Kuan Pujan" which is the worshipping of well), there has been a marked decrease in ground water levels as people become more reliant on piped systems. A check dam was constructed in June 2005 to help recharge the aquifer. The villagers were involved in this project and helped to select the location and work as laborers. It is hoped that the check dam will help to raise ground water levels and that there will be a sustainable supply of water for the village.

After multiple discussions with the Panchayat, village people, and NGO along with an assessment trip visit to the village, it was jointly decided that a solar power groundwater pump that is sized to provide the current per capita requirement of 10 liters/day would significantly reduce the time spent by the woman collecting water. In addition, a distribution system would be constructed where the water could be accessed at several points throughout the village. This project will likely be completed in two phases with the first phase consisting of installing a solar ground water pump and central storage location and the second phase being the construction of the distribution system. In addition, an observation well will be drilled so that the villagers can monitor the level of the aquifer and make adjustments to their water usage requirements as necessary. During the monsoon season, the villagers would still be dependent on the hand pumps. A future project could involve the harvesting of rainwater to help during these periods. Navjyoti, an NGO in New Dehli, has offered to help facilitate the project.

\section{Sophomore Design Course}

The sophomore design course is entitled "Engineering by Design." The course provides an indepth study of the design process that includes problem solving methodologies, evaluation of alternate solutions, economic analysis, ethical constraints, group dynamics, and presentation techniques. Students undertake design projects that meet these objectives with formal written report and oral presentation required at the end of the semester.

The University of Hartford has a relatively small engineering program that offers ABET accredited degrees in civil engineering (students can select an environmental concentration), mechanical engineering, electrical engineering, computer engineering, and biomedical 
engineering. The college also has a very strong program in acoustical engineering where students can earn both an engineering degree and a music degree from the University of Hartford's Hartt School. This is a unique program which attracts students from around the country while most of the other engineering students come from Mid Atlantic and New England states.

For the spring 2007 semester, 60 students registered for the Engineering by Design course of which 53 are full-time students. The full time students were given descriptions of the projects and were asked to rank the order of the projects with the intent of giving most of the students either their top or second choice. The seven part-time students do not have the same flexibility in selecting a project as the full-time students because there is only one section offered in the evening. For the full-time students, the sections are all offered at the same time so that schedule conflicts would not limit the choice of projects for any of the students. Overall, each project team will have between 10 and 15 students. Below is a description of spring 2007 projects that were given to the students.

\section{PROJECT 1: ENGINEERS WITHOUT BORDERS - DEVELOPMENT OF A DEPENDABLE WATER SUPPLY FOR ABPEYPUR, INDIA}

This project, sponsored by the Engineers Without Borders (www.ewb_usa.com) is concerned with providing safe, economic drinking water to some villagers in India. Spring 2006's section of ES242 completed a preliminary design for this project. The design includes photovoltaic (PV) panels to generate electricity, an electric pump to pump the water from a borewell. A borewell will be dug as part of this project. The design also includes a storage tank and the infrastructure required to support the tank and the PV structurally. An EWB team will be visiting India in January 2007 to conduct a comprehensive survey of the village that would provide inputs to detailed design.

A scale model of the proposed design will be constructed and tested to verify the concept and predict the output for field conditions. We will interact with Indian companies to obtain detailed cost estimates and pull together an implementation team. It is expected that some students and a faculty member will travel to India in summer 2007 for implementing the project. For this to take place, students will be required to submit a report summarizing the assessment trip findings and present their design to EWB's Technical Advisory Board (TAB) for approval. Approval by EWB's TAB is required before an implementation trip can take place. While in India, we will identify other possible projects such as water purification systems, water harvesting systems, education, and other power generation technologies that might be appropriate for the village. These potential projects will be the basis for a spring 2008 ES 242 project.

\section{PROJECT 2: DESIGN AND PERFORMANCE OF SOLAR CELLS}

So called "solar cells" use the photovoltaic effect to convert sunlight into electrical current. The simplicity of this direct conversion has, in part, been responsible for a six fold increase in the use of solar cells (now referred to as photovoltaic cells) over the last ten years. However, one drawback of current, silicon based, photovoltaic cells, is that less than $25 \%$ of the incident 
sunlight is converted to electrical current. Thus, a large numbers of cells are required and, without government subsidy, cost about 10 times per kilowatt-hour of electrical energy, as fossil fuel generated energy. However, they produce zero greenhouse gases.

The University of Hartford has installed a 17 kilowatt array composed of 63 individual cells, mounted on three arrays, on the roof of Lincoln Theater. In the six months of operation the arrays have generated about $10 \mathrm{MW}$-hr of energy. This energy represents about $10 \%$ of the energy used by Lincoln Theater.

This project will be centered on use of the conversion data base from operation of these arrays. The project will include inspection of the Lincoln Theater arrays, construction of desk-top photovoltaic operated fans and or lamps, review of the theory and performance of photovoltaic cells, sizing and design of solar arrays, comparison of array performance with predictions, improvements in photovoltaic cell manufacture and design, and a possible visit to Spire, Inc. (a manufacturer of silicon for solar cells and computer chips).

\section{PROJECT 3: DEVELOPMENT OF A SYSTEM TO AUTOMATICALLY DETECT AND STOP AN APNEA EVENT}

Apnea, the cessation of breathing, continues as a major health problem for infants, especially those who are prematurely born. Most premature babies who are in newborn intensive care units have apnea. Furthermore for sick newborns or for newborns at risk for sudden infant death syndrome (SIDS), apnea is a life-threatening event. Currently apnea may be treated with medications or in the newborn intensive care unit with respirators. For milder conditions a caretaker such as a nurse responds to a cardio-respiratory monitor alarm and physically shakes or stimulates a child's body or extremity. All of these treatments have risks. Medication risks are side effects, raising heart rates, prohibiting sleep and causing gastrointestinal symptoms. Ventilators may cause respiratory infections and lung injuries. A nurse often responds to an alarm in a delayed fashion and, if she had been caring for another patient, in an unsanitary manner. Neonatologist, Leonard Eisenfeld M.D., Connecticut Children's Medical Center has developed a mechanical vibrotactile stimulator. The University of Hartford group is working under his supervision to bring this innovation closer to production.

The above project and a second project to listen to the Bowel Sounds of infants after feeding via a feeding tube will be pursued in this class. Both paper designs and hands-on prototypes will be developed.

\section{PROJECT 4: DESIGN ACOUSTICAL TREATMENTS FOR THE GREAT HALL AT THE HARTFORD TRAIN STATION}

The Great Hall is a large, open waiting room area within the Train Station in downtown Hartford. It currently has poor speech intelligibility, and efforts to utilize the space for live concerts have resulted in excessive build up of sound and muddy, unclear musical experiences. The students would analyze the current acoustical characteristics of the Great Hall 
by making on-site acoustical measurements as well as modeling the acoustic behavior in a spreadsheet. The students would determine the type, amount and location of surface treatments and wall/ceiling configurations to achieve proper sound dispersion during the rooms' intended uses.

\section{Analysis of Student Interest}

Forty-two of the 53 full-time students (79\%) of the students submitted the survey form by the due date. For those students who did not fill out the form, they will be assigned projects to even out the number of students working on each project and to provide a breadth of majors working on each project. The results of the students' top selection are shown in Figure 1. Because of the low number of students in many of the majors that submitted the survey, the level of interest in each project may vary significantly from year to year. Also, the relatively high percentage of students interested in a focused field such as acoustical engineering may not make these results representative of other engineering programs. However, the results do provide some preliminary insight into the level of interest for these types of projects by our students. The design for developing communities' project was selected by only about $20 \%$ of the students. It was expected that this project would attract much more interest especially since there is a very good chance that the students' trip to India will be completely funded so that they can implement their design. However, the size of the team ( 8 students) to work on this project is a good number for the first offering of this type of project. (It should be noted that traveling to India for implementation of the project is not a requirement of the course, but is considered an opportunity that most of these students will take advantage of.) Even though the project has a very large civil engineering component, only $20 \%$ of the students selected the design for developing community project (see Figure 2). The major that had the most interested in this project were mechanical engineers with $60 \%$ of the mechanical engineers (not including mechanical engineers with acoustic concentration) selecting this project. This was not all unexpected because the EWB student chapter was started by and continues to be directed through the ASME student chapter. For this small sample size, none of the biomedical, computer, mechanical with acoustics concentration, and acoustics and music majors selected the design for developing community project as their first choice.

The most popular project was the design of acoustical treatments for the Hartford train station with about $40 \%$ of the students selecting this project. This project was selected by all the acoustic \& music majors and all but one of the mechanical engineer majors with acoustics concentration. Because many of these students are very motivated to learn about a relatively focused area of engineering compared to the much broader majors such as civil, mechanical, and electrical engineering, it is not unexpected that they would want to get involved in an acoustics project during their sophomore year. Otherwise, they must wait until their senior year when they work on two acoustics projects. It is interesting to note that about $35 \%$ of these students selected the design for developing community project as their second choice. In subsequent years, it is anticipated that some of these students would select the engineering for developing community project after hearing about the on-location experiences from students who have completed an implementation trip. As for civil engineering students, the acoustics project was likely very attractive because of its architectural aspect. 


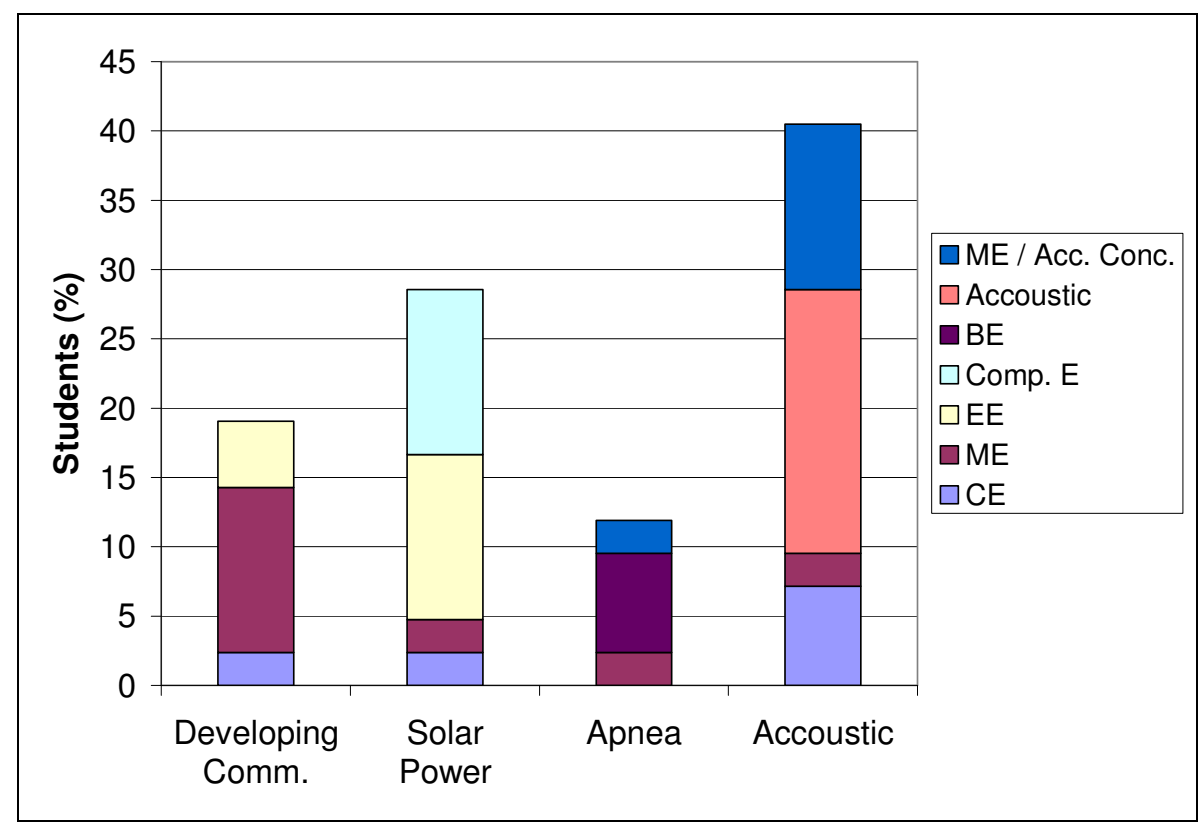

Figure 1. Sophomore Student Interest in Design Projects

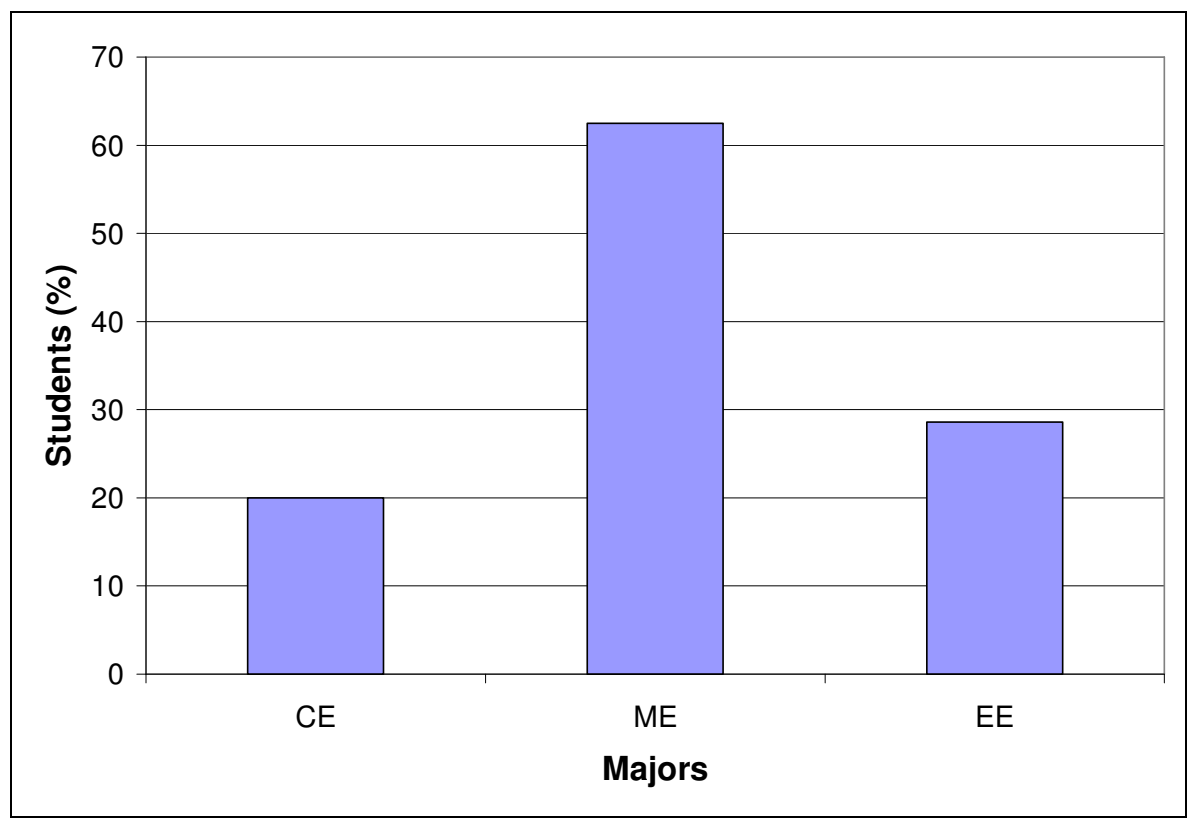

Figure 2. Student Interest in Design for Developing Community Project by Major 


\section{Conclusion}

While the initial level of interest in a design for developing community project was less than anticipated, it is thought that student interest would grow in subsequent years when the EWB projects become more established and more students relay their experiences to the next class of sophomore students. One potential advantage for the University of Hartford engineering program is that this type of opportunity should help to attract a different type of engineering student that is more involved in community service and global issues. Because many of the projects have a strong civil / environmental engineering component, it is hoped that a high percentage of these students will enter the civil engineering program. Also, there appears to be an opportunity to attract students who would not otherwise be interested in engineering into the engineering program. In order to achieve this, it will be necessary for us to work with the admissions office so that they can promote this type of opportunity to all high school students, not just those students who already have an interest in engineering.

\section{Bibliography}

1. Engineers Without Borders Website, http://eba-usa.com

2. University of Hartford's Website, http://www.hartford.edu/about/info.asp?item=Mission

3. Pines, D. and M. Keshawarz, "Town Government, Industry, and University Involvement in the Capstone Design Course at the University of Hartford," 2001 ASEE Annual Conference, Albuquerque, NM, 2001.

4. Pines,D., "Including Service Learning into the Environmental Engineering Curriculum," 2004 ASEE Annual Conference, Salt Lake City, UT, 2004.

5. Pines, D., J. Fuller, T. Hahn, and N. Wynn, "Bringing Together Engineering, Architecture, and Art Students to Creatively Solve Community Design Issues," 2005 ASEE Annual Conference, Portland, OR, 2005.

6. Pines, D., "Providing Engineering Students a Global Perspective through a Project for Developing Communities - Lessons Learned at the University of Hartford," 2006 ASEE Annual Conference, Chicago, IL, 2006. 